\title{
O CONTEÚDO AXIOLÓGICO-NORMATIVO DA PROPRIEDADE E SUA FUNÇÃO SOCIAL
}

\section{Luiz Fernando Rossetti Borges ${ }^{1}$}

\section{Resumo}

O presente artigo visa analisar a conformação do direito de propriedade pós-Constituição de 1988. Para tanto, fazse um breve resumo de seu conteúdo político e econômico e a interação que exerce no modo de produção econômico capitalista a partir da teoria do valor de Adam Smith, apontando as consequências no nascente capitalismo brasileiro. Não obstante, investiga-se as constituições republicanas do Brasil e o delineamento que conferem a ela, para assim analisar a propriedade-função atual e o seu caráter promocional, a qual, por certo, não possui inspiração socialista. Está, por outro lado, em consonância com uma economia solidarista e comprometida com a justiça social e a igualdade material. Nesse sentido, diferencia-se a função social da limitação jurídica da propriedade, pois àquela é de caráter positivo e insere-se em seu próprio conteúdo e a limitação é de cunho negativo e acha-se na face externa do instituto. Após, diferencia-se qual a propriedade que está obrigatoriamente vinculada ao cumprimento da função social, notadamente dos bens de produção e bens imóveis, daquela propriedade que possui somente função individual ou de fruição imediata. São abordados também julgados provenientes dos tribunais superior do Brasil, observando ora posicionamentos conservadores, ora entendimentos oxigenados a nova conformação do direito de propriedade alinhado a sua inerente função social. Por afim, aborda-se os aspectos da existência e da eficácia da propriedade que não possua finalidade social.

Palavras-chave: Direito Constitucional. Direito Civil. Propriedade. Função Social.

\section{INTRODUÇÃO}

Ao longo dos tempos, a propriedade passou por profundas transformações, tanto em seu aspecto legal, quanto em sua estrutura, pois ela é dinâmica e seu conteúdo será determinado de acordo com as transformações das relações de produção.

Neste diapasão, a concepção de que a propriedade é absoluta, perpétua e exclusiva advinda do direito romano não se aplica mais à luz da Constituição de 1988, pois sobre ela recai grave encargo social, bem como está submetida a inúmeras limitações.

\footnotetext{
${ }^{1}$ Pós-graduado em Direito Penal e Processo Penal na Universidade do Vale do Itajaí (UNIVALI). Assessor Jurídico do Centro de Apoio Operacional do Meio Ambiente (CME) do Ministério Público do Estado de Santa Catarina (MPSC). E-mail: luizrossettiborges@gmail.com
} 
Partindo desse pressuposto, o presente artigo objetiva demonstrar que o instituto da propriedade sofreu profunda transformação, uma vez que o direito, especialmente a disciplina da propriedade na Constituição da República, somente tutelará a aquela propriedade efetivadora da função social.

O tema foi escolhido primordialmente em razão da necessidade de colocar em discussão o impositivo constitucional da função social da propriedade, haja vista o tratamento conferido pela doutrina majoritária e pela jurisprudência se darem de forma restritiva e engessada. $\mathrm{O}$ debate se torna atual na medida em que os problemas sociais presentes no País parecem ser insolúveis. Deve-se assinalar que compete também ao direito propor medidas e interpretações jurídicas com o desígnio de diminuir a exclusão social.

Torna-se de extrema importância o tema em questão, pois a desigualdade e a exclusão sociais parecem se agravar no Brasil, relacionados principalmente a políticas econômicas que visam retirar o Estado como principal indutor do desenvolvimento e seu principal responsável. O cumprimento da função social da propriedade pode redefinir a distribuição de bens necessários a uma vida digna, uma vez que, no sistema de produção, o acesso à propriedade é o único meio de obtenção de direitos fundamentais.

Ademais, o tema sofre preconceito por parte significativa de juristas, motivo pelo qual sua abordagem tende a ser de forma limitada e superficial, não the conferindo tratamento adequado e não lhe demonstrando seu longo alcance. Em vista disso, o pretendido ineditismo do presente trabalho está no resgate do sentido dado pela doutrina crítica à função social da propriedade e na profunda transformação social que a aplicação deste mandamento constitucional pode obter.

Ressalta-se que, muito embora a doutrina e a jurisprudência majoritárias reconheçam a relevância da função social da propriedade, hesitam na sua fixação e aplicação, ora conferindo ao instituto um caráter subsidiário à propriedade, ora tornando-o um princípio constitucional meramente programático e sem efeito, não entendendo a radical transformação no conteúdo axiológico-normativo da propriedade.

\section{ESCORÇO HISTÓRICO-AXIOLÓGICO SOBRE A PROPRIEDADE}

A investigação histórico-axiológica da propriedade passa necessariamente pela análise de seu conteúdo político e econômico e pela interação que exerce no modo de produção econômico capitalista, dada a essencialidade do vetusto instituto em sua configuração.

Os contornos atuais da propriedade foram inicialmente traçados a partir da Revolução Burguesa na França, ocasião em que, inaugurada a Primeira República, ganhou feição absoluta, sagrada e extremamente individualista, rememorando os caracteres da propriedade romana (GILISSEN, 2013, p. 645). Observam-se os traços da propriedade contemporânea no artigo 17 da Declaração dos Direitos do Homem e do Cidadão, de 1789, in verbis: 
Como a propriedade é um direito inviolável e sagrado, ninguém dela pode ser privado, a não ser quando a necessidade pública legalmente comprovada o exigir evidentemente sob condição de justa e prévia indenização.

Pode ser também verificado este caráter proprietário e individualista no artigo 544 do Código Napoleônico: "a propriedade é o direito de gozar e dispor das coisas do modo mais absoluto, desde que não se faça uso proibido pelas leis ou regulamentos". A teoria do abuso do direito, como se observa, é desenvolvida, iniciando a limitação ao direito do proprietário, ainda que timidamente.

Para compreender a centralidade e a importância do instituto da propriedade no Code Civil, colacionase da obra de John Gilissen (2013, p. 537) a seguinte passagem:

A propriedade é individual; na época do Code, o pai de família é "bom" se se torna proprietário e deixa filhos. Três quartas partes dos artigos do Code são consagrados a esta propriedade que é, sem que isso se diga, essencialmente concebida como a de um indivíduo e não como a de um grupo ou de uma colectividade; e este indivíduo, o proprietário, pode fazer dela o que muito bem the pareça.

O ideário liberal, insculpido na Declaração de 1789 e no Código de Napoleão, foi construído por cerca de três séculos, ancorado em pensadores como John Locke e Adam Smith.

O bem jurídico de maior envergadura para o John Locke (1632-1704) é a propriedade (vida, corpo, saúde, liberdade e todos os bens conquistados pelo trabalho). Ao retirar um objeto da natureza e transformá-lo em coisa diversa, passa a ser sua, excluindo todos os outros ao acesso do bem. Para tanto, o referido jusnaturalista (2009, p. 25) afirma que "o trabalho de removê-los daquele estado comum em que estavam fixou meu direito de propriedade sobre eles". Na mesma linha, diz que, ao trabalhar na terra, estabelece-se o direito proprietário sobre ela, pelo mesmo critério já estabelecido, o trabalho.

Deve ser pontuado que o direito de propriedade em John Locke é eminentemente justificado pelo divino, como um direito natural ao homem. Nesse sentido, justifica:

Da mesma forma que Deus, ao dar a ordem para subjugar as coisas, habilitou o homem a se apropriar delas. A condição da vida humana, que necessita de trabalho e de materiais para serem trabalhados, introduz forçosamente as posses privadas (2009, p. 25).

A origem divina da propriedade faz parte do contexto político-social da época em que viveu John Locke e atua como elemento essencial para a configuração quase absoluta desse direito marcantemente individualista. Assim, aparece a propriedade privada quase que intocável, elevando-se ao próprio fundamento do Estado, devendo exercer o múnus de tutelar e de conservar a propriedade privada e pertencente ao indivíduo.

Adam Smith (1723-1790) contribuiu significativamente para o aprimoramento do conceito da propriedade, inspirado pela Revolução Industrial, no bojo do nascente capitalismo, em que se passou a utilizar máquinas e a remunerar o trabalho de forma assalariada.

O citado economista político (1996, p. 87/88), a exemplo de Locke, conferiu ao trabalho humano importante envergadura para a definição do conceito de propriedade, indicando o trabalho como a medida invariável de valor. 
Adam Smith é considerado na literatura o pai da teoria do valor-trabalho, fator responsável pela geração de valor às mercadorias, atuando como única medida fixa do preço. Extrai-se da obra o seguinte excerto:

O trabalho foi o primeiro preço, o dinheiro de compra original que foi pago por todas as coisas. Não foi por ouro ou por prata, mas pelo trabalho, que foi originalmente comprada toda a riqueza do mundo; e o valor dessa riqueza, para aqueles que a possuem, e desejam trocá-la por novos produtos, é exatamente igual à quantidade de trabalho que essa riqueza lhes dá condições de comprar ou comandar.

Sinteticamente, para Adam Smith, a quantidade de trabalho que pode ser comprada com um produto foi a forma de estabelecer uma unidade de mensuração de valor para as mercadorias, razão pela qual explica que "o trabalho é a medida real do valor de troca de todas as mercadorias" (1996, p. 87). Nesse sentido, o comércio como troca de equivalentes entre diferentes nações é a quantidade de trabalho empregada em cada mercadoria (1996, p. 91/92). Esta, frise-se, é a resposta para a pergunta inicial feita em sua obra: qual seria a causa da riqueza das nações? É justamente a capacidade de uma nação exportar pouco trabalho e comprar em quantidade maior de trabalho das outras nações, condensada na forma de mercadorias.

Na esteira do pensamento liberal, foi promulgada no Brasil a Lei de Terras (Lei n. 601, de 18 de setembro de 1850), pela qual foram proibidas aquisições de terras devolutas por outro título que não fosse o da compra. Dificultou-se sobremaneira o acesso à propriedade imobiliária rural, cristalizando o direito daqueles que já a ocupassem, notadamente dos herdeiros das sesmarias. Transmudou-se, assim, o status da propriedade para mercadoria, tornando-a comercializável e apta a produzir lucros por meio do trabalho (GADELHA, p. 155).

As medidas liberais implementadas pelo Estado brasileiro, visando o desenvolvimento do capitalismo em solo nacional, não se esgotaram na Lei de Terras, mas também produziram a Lei Eusébio de Queirós (Lei n. 581, de 4 de setembro de 1850), que proibiu o tráfico de escravos no País como forma de incrementar o mercado interno por meio do trabalho assalariado (GADELHA, p. 160).

Partindo-se da teoria do valor de Adam Smith, entende-se que a propriedade imobiliária ganha valor comercial por meio do trabalho, exercido pelo homem, motivo que ensejou a edição da Lei de Terras e da Lei Eusébio de Queirós.

Em contraposição ao capitalismo que se desenvolvia alicerçado na doutrina liberal, foi a partir do catolicismo político de Jacques Maritain e dos ensinamentos de Emmanuel Mounier que efetivamente se iniciaram algumas contribuições para a formação de uma ideia segundo a qual recaía sobre a propriedade privada um encargo social.

A Encíclica Rerum Novarum (1891), do Papa Leão XIII, constitui-se como resposta a pressões populares da segunda metade do século XIX, resultantes das péssimas condições de vida dos trabalhadores da época e do recrudescimento da doutrina socialista. Apesar de pequenos sinais de busca da função social da 
propriedade contidos na Encíclica, é notadamente ao filósofo do direito Léon Duguit que se atribui a postulação da ideia de que a propriedade deveria cumprir uma função social. Para Léon Duguit (2009, p. 48):

O próprio direito de propriedade só deve ser atribuído a certos indivíduos que se encontrem numa característica situação econômica, como poder de desempenhar livremente a missão social que thes cabe em virtude da sua situação especial.

Nesse ponto, começaram a se desenhar, no século XX, constituições que visavam impingir ao proprietário deveres ao bem comum. Nesse mesmo sentido, apresenta-se a Constituição da República do Brasil de 1988, dentre outras que se passa a analisar.

\section{BREVES APONTAMENTOS SOBRE AS CONSTITUIÇÕES DA REPÚBLICA E A PROPRIEDADE}

É nítida a preocupação do legislador, no bojo da Constituição da República de 1988, democrática e social, intervencionista e garantidora do estado de bem-estar social, em criar mecanismos de correção de desigualdades naturalmente provocadas pelo sistema econômico. O legislador originário fez constar como objetivo fundamental da República "erradicar a pobreza e a marginalização e reduzir as desigualdades sociais e regionais" (art. $\left.3^{\circ}, \mathrm{III}\right)$, assim como também o é como princípio da atividade econômica. Não obstante, extrai-se do mesmo dispositivo: "promover o bem de todos" (art. $3^{\circ}$, IV) e promover a "dignidade da pessoa humana" (art. $1^{\circ}$, III), bem como "assegurar a todos existência digna" (art. 170, "caput").

Exsurgem dessas normas, por conseguinte, os conceitos de justiça social e isonomia material, diametralmente opostos ao ideário liberalizante da justiça e igualdade formais. Ademais, a ideologia e a parafernália neoliberal, implementada no Brasil a partir dos anos de 1990, é veementemente repudiada pelo ordenamento jurídico brasileiro. A esse respeito, acerca da intervenção do Estado no domínio econômico e social, detalhada no art. 170 da CR, explica Celso Antônio Bandeira de Mello (2010, p. 793):

À vista dos dispositivos citados, é claro a todas as luzes que a Constituição brasileira apresenta-se como uma estampada antítese do neoliberalismo, pois não entrega a satisfatória organização da vida econômica e social a uma suposta (e nunca demonstrada) eficiência do mercado. Pelo contrário, declara que o Estado brasileiro tem compromissos formalmente explicitados com os valores que nela se enunciam, obrigando a que a ordem econômica e a social sejam articuladas de maneira a realizar os objetivos apontados. Com isto, arrasa liminarmente e desacredita do ponto de vista jurídico quaisquer veleidades de implantação, entre nós, do ideário neoliberal. Aliás, uma verdadeira aberração do ponto de vista do neoliberalismo é o disposto no art. 219, de acordo com o qual: 'O mercado interno integra o patrimônio nacional e será incentivado de modo a viabilizar o desenvolvimento cultural e sócio-econômico, o bem-estar da população e a autonomia tecnológica do País, nos termos de lei federal'. 
Aparecem no texto normativo constitucional normas definidoras de direitos e garantias fundamentais, com aplicação imediata $\left(\operatorname{art.} 5^{\circ}, \mathbb{S} 1^{\circ}\right)$, assim como normas programáticas ${ }^{2}$, com o fulcro de conferir ao Estado determinados objetivos a serem cumpridos, isto é, prestações de ordem positiva à sociedade.

A despeito deste entendimento acerca da presença de normas programáticas na Constituição da República, devem ser entendidas as normas constitucionais como imediatamente vinculantes e possuidoras de inegável imperatividade. Para tanto, colaciona-se clássica passagem de Ruy Barbosa (1933, p. 489): "não há, numa Constituição, cláusulas a que se deva atribuir meramente o valor moral de conselhos, avisos ou lições. Todas têm a força imperativa de regras".

Nesse sentido, não se pode entender a Constituição Federal de 1988 como simples "constituição dirigente" (BERCOVICI, 1999), pois ela confere efetivamente ao Estado a obrigação de buscar e concretizar uma democracia substancial.

A esse respeito, sobre o contexto histórico que a Constituição está atualmente inserida, a partir do século $\mathrm{XX}$, viu-se a progressiva derrocada das Constituições liberais, na medida em que os governantes e os constitucionalistas se viram obrigados a encontrar soluções para os crescentes conflitos sociais.

As constituições do início do último século, mais especificamente após a Primeira Grande Guerra, com destaque às Constituições Mexicana (1917), e, principalmente, da República de Weimar (1919), começaram a apresentar normas programáticas e a preocuparem-se com os direitos sociais. Assim faz constar Paulo Bonavides (2010, p. 232/233):

Quando as Constituições do liberalismo, ao construírem um Estado de Direito sobre bases normativas, pareciam haver resolvido a contento, durante o século XIX, esse desafio, eis que as exigências sociais e os imperativos econômicos, configurativos de uma nova dimensão da Sociedade a inserir-se no corpo jurídico dos textos constitucionais, trouxe à luz a fragilidade de todos os resultados obtidos. As antigas Constituições, obsoletas ou ultrapassadas viram então criar-se ao redor de si o clima da programaticidade com que os modernos princípios buscavam cristalizar um novo direito, por onde afinal se operou a elaboração das Constituições do século XX: inaugurava-se assim a segunda fase - até agora não ultrapassada de programaticidade das Constituições. Programaticidade que nós queremos seja 'jurídica', e não 'programática', isto é, sem positividade.

Direitos sociais concernentes às relações de produção, ao trabalho, à educação, à cultura, à previdência, representavam uma estupenda novidade, um campo por inteiro distinto, desconhecido ao Direito Constitucional clássico. Mas dificilmente as declarações que os

2 Para José Afonso da Silva, "As normas programáticas são de grande importância, como dissemos, porque procuram dizer para onde e como sei vai, buscando atribuir fins ao Estado, esvaziado pelo liberalismo econômico. Essa característica teleológica lhes confere relevância e função de princípios gerais de toda a ordem jurídica, como bem assinala Natoli, tendente a instaurar um regime de democracia substancial, ao determinarem a realização de fins sociais, através da atuação de programas de intervenção na ordem econômica, com vistas a assegurar a todos existência digna, conforme os ditames da justiça social. Esta é o fim que os arts. 170 e 193 da Constituição de 1988 prescrevem para as ordens econômica e social. Não é fácil realizar a justiça social num sistema em que predomina a concentração da riqueza. É que ela só se concretizará mediante equitativa distribuição da riqueza nacional, pois um regime de justiça social será aquele em que cada um deve poder dispor dos meios materiais de viver confortavelmente segundo as exigências de sua natureza física, espiritual e política. Um sistema democrático de justiça social não aceita as profundas desigualdades, a pobreza e a miséria" (Aplicabilidade das normas constitucionais. 3a ed. São Paulo: Malheiros, 1998, p. 141). vol.09, nº. 01, Rio de Janeiro, 2016.pp. 15-38 
inseriam se prestavam a uma redução jurídica fácil, de modo a fazê-los ingressar no corpo da Constituição dotados já de aplicabilidade direta e imediata. Os princípios sociais enunciados pela Constituição oferecem obstáculos muito mais sérios a uma conversão em direitos subjetivos correlatos do que os antigos direitos da liberdade proclamados ao alvorecer do constitucionalismo liberal, conforme ponderou Virga com penetrante acuidade.

Como principal exemplo dessa nova visão, a Constituição da República de Weimar, no ano de 1919, incorporou definitivamente em discussões jurídicas a função social da propriedade, com a previsão consubstanciada na passagem "a propriedade obriga" (Eigentum verpflichtet).

No Brasil, a primeira previsão constitucional da função social da propriedade, ainda que de forma tímida e embrionária, ocorreu na Constituição da República dos Estados Unidos do Brasil de 1934. Esta Constituição, em seu artigo 17, dispunha que: "é garantido o direito de propriedade, que não poderá ser exercido contra o interesse social ou coletivo, na forma que a lei determinar", colocando fim à visão estritamente individualista sobre a propriedade. A Constituição de 1934 foi promulgada no primeiro governo de Getúlio Vargas, ainda se ressentindo o Brasil da crise que assolara o mundo em 1929. No bojo de pressões populares, bem como do próprio Estado de São Paulo, restabeleceu-se a democracia, trazendo garantias aos trabalhadores e direitos sociais relacionados à saúde, educação e cultura.

Passa-se em branco pela Constituição do Estado Novo de 1937, elaborada pelo jurista Francisco Campos, na qual foi refletida uma tendência nitidamente fascista, inspirada em regimes autoritários europeus, não sendo impingida à propriedade qualquer gravame de ordem social, apesar de no art. 122, 14³ desta Constituição prever que a limitação e a definição do conteúdo da propriedade se dariam em leis infraconstitucionais.

Com a derrubada dos regimes fascistas europeus após a Segunda Grande Guerra, Getúlio Vargas foi substituído por Eurico Gaspar Dutra, o qual tratou de promulgar uma Constituição adequada à nova conjuntura internacional. Assim, com o retorno de diversas garantias e direitos individuais retirados da Carta de 1937, novamente condicionou-se, na Constituição de 1946, o uso da propriedade ao bem-estar social ${ }^{4}$, em seu artigo 147, mas apresentou uma novidade: obrigou o Estado, já na esteira da onda de constituições dirigentes, a promover a justa distribuição da propriedade.

Foi somente na ditadura iniciada pelos militares em 1964, na Constituição outorgada de 1967, que a função social da propriedade foi incluída no rol dos princípios da ordem econômica, em seu inciso III, artigo $157^{5}$, com o desígnio de promover e realizar a justiça social, mantendo-se, como se vê, o já cristalizado instituto. Não obstante ter sido esta Carta Constitucional profundamente modificada com a Emenda Constitucional n. 1 de

3 "Art 122 - A Constituição assegura aos brasileiros e estrangeiros residentes no País o direito à liberdade, à segurança individual e à propriedade, nos termos seguintes: [...] 14) o direito de propriedade, salvo a desapropriação por necessidade ou utilidade pública, mediante indenização prévia. O seu conteúdo e os seus limites serão os definidos nas leis que lhe regularem o exercício;”.

4 "Art 147 - O uso da propriedade será condicionado ao bem-estar social. A lei poderá, com observância do disposto no art. 141, $\mathbb{S}$ 16 , promover a justa distribuição da propriedade, com igual oportunidade para todos”.

5 Art 157 - A ordem econômica tem por fim realizar a justiça social, com base nos seguintes princípios:

[... ] III - função social da propriedade;" 
1969, repetiu-se tal previsão. Deve-se pontuar, por outro lado, que esse dispositivo constitucional era somente satisfatoriamente suscitado ao se tratar da desapropriação com fins à reforma agrária ${ }^{6}$.

A Constituição da República Federativa do Brasil atual, não somente fez permanecer a função social da propriedade como princípio da ordem econômica (art. 170, III), mas também a incluiu no rol do art. $5^{\circ}$, XXIII, como direito e garantia individual. Esta repetição, por certo, trouxe novos reflexos à configuração do instituto, no entender de José Afonso da Silva (2003, p. 280):

A propriedade atenderá a sua função social, diz o art. $5^{\circ}$, XXIII, para a propriedade em geral. Essa disposição bastava para que toda forma de propriedade fosse intrinsecamente permeada daquele princípio constitucional, mas a Constituição não se limitou a isso. Reafirmou a instituição da propriedade privada e a sua função social como princípios da ordem econômica (art. 170, II e III), relativizando, assim, seu significado, como vimos. Além disso, inscreveu o princípio da função social da propriedade, com conteúdo definido em relação às propriedades urbana e rural, com sanções para o caso de não ser observado (arts. 182,184 e 186) [...].

A inserção da função social no ordenamento jurídico brasileiro, como se observa, foi lenta e gradual, e somente na atual Constituição as espécies de propriedades, regra geral, passaram a ser condicionadas e justificadas a partir da realização da sua finalidade social. Extrai-se dessas suas características o conteúdo da propriedade e a sua dimensão promocional.

\section{O CONTEÚDO E A DIMENSÃO PROMOCIONAL DA FUNÇÃO SOCIAL}

No âmbito da propriedade, além das intervenções diretas do Estado na atividade econômica (com vistas à realização daqueles objetivos inscritos no artigo $3^{\circ}$ da Constituição da República ${ }^{7}$ ) e das limitações impostas pelo legislador, originário e derivado, também obrigou o próprio indivíduo a prestar contas à sociedade no tocante ao seu patrimônio. Esta prestação de contas do proprietário se funda na completa transformação do conceito da propriedade, conforme ensina Orlando Gomes (2010, p. 122/123):

A resposta segundo a qual a função social da propriedade é antes uma concepção com eficácia autônoma e incidência direta no próprio direito consente elevá-la à dignidade de um princípio que deve ser observado pelo intérprete, tal como sucede em outros campos do Direito Civil, como o princípio da boa-fé nos contratos. É verdade que assim considerada se torna uma noção vaga, que, todavia, não é inútil na medida em que inspira a interpretação da atividade do proprietário. Nessa ótica, a ação do juiz substitui a do legislador, do Congresso ou da Administração Pública. O comportamento profissional do magistrado passa a ser, no particular, 'uma ação de invenção e de adaptação', como se exprime Lanversin definindo a ação pretoriana como um meio de realizar a modernização do direito. É verdade que, nessa colocação, se corre o risco de um uso alternativo do direito ou de uma resistência

6 Cumpre consignar que o Estatuto da Terra (Lei n ${ }^{4}$ 4504/64), importante instrumento para a desapropriação de propriedades que não cumpriam com a sua função social, na esteira de reformas agrárias que aconteciam em parte da América Latina, veio para tentar abrandar as lutas camponesas que começavam a surgir no país.

7 Art $3^{\circ}$ Constituem objetivos fundamentais da República Federativa do Brasil: I - construir uma sociedade livre, justa e solidária; II - garantir o desenvolvimento nacional; III - erradicar a pobreza e a marginalização e reduzir as desigualdades sociais; IV promover o bem de todos, sem preconceitos de origem, raça, sexo, cor, idade e quaisquer outras formas de discriminação. vol.09, no. 01, Rio de Janeiro, 2016.pp. 15-38 
empedernida. Como quer que seja, o preceito constitucional que atribui função social à propriedade não tem valor normativo porque não se consubstancia nas normas restritivas do moderno direito de propriedade, mas simplesmente se constitui no seu fundamento, na sua justificação, na sua ratio.

É nessa reformulação de conceito, em uma nova ratio, que se apresenta a função social da propriedade. O proprietário fica, nesse contexto, condicionado a utilizar a propriedade com o fim de promover o bem-estar social. É importante ressaltar, todavia, o entender do célebre teórico soviético no campo do direito, Evgeni Bronislávovich Pachukanis (1988, p. 59), o qual sustenta a hipocrisia dos juristas ditos burgueses na defesa da função social da propriedade, por não haver, efetivamente, alterações substanciais no conceito de propriedade:

Gojchbarg, em seu comentário ao Código Civil da URSS, salienta que os juristas burgueses progressistas estão começando a considerar a propriedade privada não mais como um direito subjetivo arbitrário, mas sim como um bem-posto à disposição da pessoa. Ele se refere diretamente a Duguit, o qual afirma que o possuidor do capital só deve ser juridicamente passível de proteção apenas porque exerce, mediante justa colocações do seu capital, funções socialmente úteis.

Tais considerações dos juristas burgueses são com efeito características, pois revelam o sintoma do declínio da época capitalista. Mas a burguesia, por outro lado, somente tolera tais considerações acerca das funções sociais da propriedade, porque elas em nada a comprometem. Antítese real da propriedade não é efetivamente a propriedade concebida como função social, mas a economia planificada socialista, isto é, a supressão da propriedade. A propriedade privada não encontra seu sentido, seu subjetivismo, no fato de 'cada um comer o seu próprio pão', isto é, não consiste no ato de consumo individual, mesmo que igualmente produtivo, mas na circulação, no ato de apropriação e de alienação, na troca de mercadorias em que o fim econômico-social não é senão o resultado cego de fins privados e de decisões privadas autônomas.

A explicação de Duguit, mediante a qual o proprietário deve ser protegido apenas quando cumpre as suas obrigações sociais, não tem, sob esta forma geral, qualquer sentido. No Estado burguês é uma hipocrisia, no Estado proletário é uma dissimulação dos fatos. Porque se o Estado proletário pudesse relegar diretamente cada proprietário à sua função, já o teria feito tomando aos proprietários o direito de dispor da própria propriedade. Porém, se economicamente é incapaz disso, ele deve proteger o interesse privado como tal e fixar-lhe apenas certos limites. Seria ilusório afirmar que qualquer indivíduo que tenha conseguido dentro das fronteiras da União Soviética acumular uma cerca quantidade de dinheiro, é protegido pelas nossas leis e pelos nossos tribunais apenas porque encontrou ou encontrará uma utilização social proveitosa para a quantia acumulada. Aliás, Gojchbarg parece ter esquecido completamente a propriedade como capital, considerada na sua forma mais abstrata, monetária, raciocinando como se o capital não existisse a não ser sob a forma concreta de capital de produção. Os aspectos anti-sociais da propriedade privada não podem ser paralisados senão de fato, ou seja, mediante o desenvolvimento da economia planificada socialista, em detrimento da economia de mercado. Porém, nenhuma espécie de fórmula, ainda que seja tirada das obras dos mais progressistas juristas da Europa Ocidental, pode tornar socialmente úteis os contratos jurídicos firmados com base em nosso Código Civil e transformar cada proprietário em uma pessoa exercendo uma função social. Tal supressão verbal da economia privada e do direito privado tende apenas a obscurecer a perspectiva da sua supressão real.

Nessa ordem de ideias, Orlando Gomes (2010, p. 121) não observa na função social "inspiração socialista, como se supõe, por desinformação, particularmente os socialistóides levianos ou contrabandistas de ideias". No entanto, apesar de ser válido e coerente o pensamento de Pachukanis, deve-se reconhecer que a 
efetivação da propriedade-função é um passo importante, ainda que acanhado, a melhoras significativas na produção e reprodução das condições de existência dos indivíduos, ao relativizar este direito nuclear ao próprio modo de produção capitalista, tornando ele desapropriável, expropriável ou nacionalizado com menor dificuldade.

Não se pode deixar de admitir, para se manter a coerência, que a imposição ao proprietário em utilizar a propriedade em favor da sociedade seja de todo infecunda na consecução dos objetivos da República e da busca por uma vida mais digna, portanto, efetivadora de uma democracia substancial. É desse pensamento contrário ao individualismo, segundo José Isaac Pilati (201 1, p. 105), que desponta a dimensão do coletivo

Da função social da propriedade, que se projeta numa República Participativa, em face de bens coletivos e atores coletivos, com desenvolvimento baseado na sustentabilidade, em prol da segurança e do bem de todos, mediante normas de ordem pública e interesse social.

Carlos Roberto Gonçalves (2010, p. 246) pondera que a propriedade deixa de ter características de direito absoluto e ilimitado, transformando-se em direito com finalidade social. Desse entendimento também compartilha o jurista italiano Pietro Perlingieri (2008, p. 226), e vai além:

Em um sistema inspirado na solidariedade política, econômica e social e ao pleno desenvolvimento da pessoa (art. 2 Const.) o conteúdo da função social assume um papel de tipo promocional, no sentido de que a disciplina das formas de propriedade e as suas interpretações deveriam ser atuadas para garantir e para promover os valores sobre os quais se funda o ordenamento. E isso não se realiza somente finalizando a disciplina dos limites à função social. Esta deve ser entendida não como uma intervenção 'em ódio' à propriedade privada, mas torna-se 'a própria razão pela qual o direito de propriedade foi atribuído a um determinado sujeito', um critério de ação para o legislador, e um critério de individuação da normativa a ser aplicada para o intérprete chamado a avaliar as situações conexas à realização de atos e de atividades do titular.

Assim sendo, pode-se dizer que o pensamento de Karl Renner (1949, p. 197) se revela atual e aplicável. Explica-se. Entendendo-se a Constituição Federal, de cunho social e democrático, inserida no bojo de um Estado intervencionista e garantidor dos direitos e garantias ali inscritos, a propriedade, seja ela pública ou privada, é símbolo e fundamento do modo de produção capitalista. Deste modo, ainda que privada, a propriedade deverá estar em consonância com uma economia solidarista e comprometida com a justiça social e a igualdade material. Reside aí, por conseguinte, o caráter positivo da função social.

Apesar desse sentido promocional da propriedade já estar bastante consolidado, parcela significativa de publicistas e civilistas reluta em admiti-lo, fazendo-se confundir as limitações ao exercício da propriedade com a função social que estrutura o seu conceito. 


\section{A DistinÇÃo ENTRE LIMITAÇÃO JURÍDICA E FUNÇÃO SOCIAL DA PROPRIEDADE}

Apesar de gravarem conjuntamente a propriedade, distinguem-se a função social das limitações, uma vez que possuem distintos fundamentos. Neste sentido, entende José Afonso da Silva (2003, p. 280/281), que:

A função social da propriedade não se confunde com os sistemas de limitação da propriedade. Estes dizem respeito ao exercício do direito ao proprietário; aquela, à estrutura do direito mesmo, à propriedade.

Do mesmo entendimento compartilha Orlando Gomes (2010, p. 122), segundo o qual "as limitações atingem o exercício do direito de propriedade, não a sua substância”. Deste modo, mister analisar, detidamente, as espécies de limitação da propriedade previstas no ordenamento jurídico brasileiro.

Para Francisco Cavalcanti Pontes de Miranda (2001, p. 51), as limitações à propriedade são classificadas em dois grandes grupos:

1. No interesse de vizinhos (direitos de vizinhança, a que correspondem deveres de vizinhança), ou

2. No interesse público, geral ou administrativo (especial), ou de algum serviço nãoestatal, que tenha interesse para o Estado.

As limitações da propriedade no interesse de vizinhos correspondem àquelas limitações, no Código Civil, em que preponderam as relações entre particulares, concernentes ao uso anormal da propriedade (art. 1.277 a 1.281); às árvores limítrofes (art. 1.282 a 1.284); à passagem forçada ao proprietário em imóvel encravado (art. 1.285) e à passagem de cabos e tubulações (art. 1.286 e 1.287); ao regime de águas entre o imóvel superior e o inferior (art. 1.288 a 1.296); ao direito e regulação de demarcação dos imóveis (art. 1.297 e 1.298) e ao direito do proprietário em construir (art. 1.299 a 1.313).

A despeito da classificação de Pontes de Miranda, há que se ressaltar no ordenamento jurídico a presença das limitações voluntárias, espécie de limitação não considerada como direito de vizinhança, sobre as quais é constituído outro direito real, como, por exemplo, no usufruto (art. 1.390 a 1.411 do Código Civil) e no estabelecimento de cláusula de inalienabilidade. As limitações provenientes da supremacia do poder público sobre o privado apresentam-se sob a forma das desapropriações (a mais contundente das limitações), servidões administrativas, requisição, ocupação temporária e limitação administrativa.

Sendo assim, os limites da propriedade, sejam regulados pelo direito privado ou oriundos da supremacia do poder público, atingirão um ou mais dos poderes conferidos ao proprietário, quais sejam, usar, gozar, dispor e 
reaver de quem quer que injustamente a possua ou a detenha ${ }^{8}$, mas não intervirão na totalidade do poder que o indivíduo exerce sobre a coisa ${ }^{9}$. A propriedade limitada continuará, desta forma, intocável em sua natureza.

Por outro lado, Orlando Gomes (2010, p. 135) consigna que as limitações da propriedade advindas da supremacia do poder público sobre o titular cresceram no último século, em que "tantas e tais têm sido as restrições ao direito de propriedade, no seu conteúdo e no seu exercício, que está abalada sua própria condição tradicional de Direito Privado".

Ademais, os encargos que gravam a propriedade, bem como as intervenções do poder público têm sido tão extensos, que o mencionado civilista compara a atual condição da propriedade àquela conhecida nos tempos feudais, quando "o domínio útil dos bens imóveis era sujeito a obrigações reais perpétuas, que deveriam ser cumpridas em proveito dos proprietários inertes, titulares do chamado domínio direto", assemelhando-se o Estado atual a um barão dos tempos modernos (2010, p. 136).

Opondo-se à dimensão negativa a que corresponde as limitações da propriedade, em que há uma evidente compressão dos direitos do proprietário sobre a coisa, a função social deve ser entendida de forma diversa, ainda que parte da doutrina nacional não assim o compreenda. Para parcela de juristas tradicionais, como Maria Helena Diniz (2006, p. 975), a função social enquadra-se em mais uma das limitações à propriedade, dado que o proprietário deixa de exercer o seu direito sobre a coisa a seu bel-prazer:

Há limitação do direito de propriedade com o escopo de coibir abusos e impedir que seja exercido, acarretando prejuízo ao bem-estar social. Com isso se possibilita o desempenho da função econômico-social da propriedade, preconizada constitucionalmente, criando condições para que ela seja economicamente útil e produtiva, atendendo ao desenvolvimento econômico e aos reclamos de justiça social.

O publicista Hely Lopes Meirelles (2010, p. 629) anui com essa tese, compreendendo o comando constitucional de atendimento à função social como simples poder de polícia da Administração, sendo o instituto uma das limitações à propriedade:

[A propriedade] é um direito individual, mas um direito individual condicionado ao bemestar da comunidade. É uma projeção da personalidade humana e seu complemento necessário, mas nem por isso a propriedade é intocável. Admite limitações ao seu uso e restrições ao seu conteúdo em benefício da comunidade. Diante dessa realidade, a Constituição da República garante a propriedade (art. $5^{\circ}$ ), mas permite a desapropriação, mediante prévia e justa indenização (art. $5^{\circ}, \mathrm{XXIV}$ ), autoriza a requisição em caso de perigo público iminente e em tempo de guerra, com indenização a posteriori (art. $5^{\circ} \mathrm{XXV}$, e 22, III), e the atribui função social (arts. $5^{\circ}$, XXIII, e 170, III).

Esse entendimento deve ser tido como ultrapassado, pois em desacordo com a nova conformação da função social, na medida em que este instituto se revela no âmbito de uma relação positiva com a sociedade, mediante a utilização da propriedade no interesse de todos.

8 BRASIL. Lei n. 10.406, de 10 de janeiro de 2002.Art. 1.228. Institui do Código Civil. Disponível em: <http://www.planalto.gov.br/ccivil/leis/2002/L10406.htm>. Acesso em: 25.05.2015.

9 A exceção está no direito do Estado em desapropriar o bem do particular, como dispõe o art. $5^{\circ}$, inciso XXIV, da Constituição da República. 
As considerações delineadas conduzem à distinta natureza jurídica das limitações jurídicas e da função social, visto que as primeiras restringem o exercício da propriedade, enquanto que a segunda submete a propriedade ao interesse coletivo.

A Constituição da República de 1988, todavia, levando-se em conta a complexidade da organização econômica capitalista e as diferentes formas jurídicas de propriedade, não obrigou todas as espécies de propriedades a atender a função social, conforme se discute em seguida.

\section{AS ESPÉCIES DE PROPRIEDADE E A VINCULAÇÃO À FUNÇÃO SOCIAL}

Partindo-se do pressuposto da existência de diversas espécies de propriedade, qual delas estaria vinculada à obrigação de atendimento à função social? No ordenamento jurídico são conhecidas as mais diversas formas de propriedade, seja intelectual, autoral, do solo, de bens de consumo, de bens de produção, e outras mais. Dentre as outras classificações, interessam inicialmente ao presente estudo as diferenças correspondentes aos bens de consumo e aos bens de produção.

Os bens de consumo são caracterizados por se destinarem a trazer alguma comodidade ao seu detentor ou então à satisfação de suas necessidades, básicas ou supérfluas. Esses bens, por suas naturezas, esgotam-se na própria fruição pelo seu titular, e, segundo Eros Roberto Grau, justificam-se "na garantia, que se reclama, de que possa o indivíduo prover a sua subsistência e de sua família” (2007, p. 238). Não deverá incidir sobre esta propriedade, portanto, a necessidade de atendimento à função social, pois ela detém somente uma função individual ou à sua família. Todavia, "entenda-se como excedente desse padrão especialmente a propriedade detida para fins de especulação ou acumulada sem destinação ao uso a que se destina” (2007, p. 238). Repreendese, portanto, qualquer forma de abuso do direito de propriedade, ainda que excluída a sua função social.

Por outro lado, os bens de produção (ou bens de capital) são aqueles que produzem outros bens, tais como máquinas, equipamentos, serviços, etc., e é sobre estas coisas que recairá a função social. Isso porque a atividade econômica na economia capitalista, como se sabe, funda-se na organização por meio da empresa, que se conceitua (COELHO, 2007, p. 18):

Como sendo atividade, cuja marca essencial é a obtenção de lucros com o oferecimento ao mercado de bens ou serviços, gerados estes mediante a organização dos fatores de produção (força de trabalho, matéria-prima, capital e tecnologia).

De tal sorte que a propriedade acumulável, nos tempos modernos, encontra-se inserida nesse processo produtivo, de forma que "apenas em relação aos bens de produção se pode colocar o problema do conflito entre propriedade e trabalho e do binômio propriedade-empresa" (2007, p. 236). Impende destacar importante passagem de Orlando Gomes (1989, p. 426) sobre o tema:

A funcionalização da propriedade se resolveria na distinção entre espécies particulares de bens, classificados mediante critério econômico, e pela modificação das normas que vol.09, nº. 01, Rio de Janeiro, 2016.pp. 15-38 
disciplinam a actividade do proprietário. Quanto aos bens, é relevante a classificação entre bens de produção, bem de uso e bens de consumo, por isso que só os bens produtivos são idôneos à satisfação de interesses econômicos e coletivos que constituem o pressuposto de fato da função social. Só apedeutas estendem aos bens de uso o princípio da função social, falando em função social da propriedade edilícia ou, até mesmo, na dos bens duráveis.

Sobre essa questão, também esclarece Fábio Konder Comparato (RDM 63/73, p. 77):

A função social da empresa - que suponho já estivesse embrionariamente postulada na contribuição de Courcelle-Seneuil, na afirmação da função social do comerciante, do proprietário e do capitalista - aparece indiretamente no art. 42 da Constituição Italiana: 'É livre a iniciativa econômica privada. Não pode, todavia, desenvolver-se em contraste com a utilidade social ou de modo a causar dano à segurança, à liberdade, à dignidade humana. A lei determina os programas e os meios de fiscalização destinados à direção e coordenação da atividade econômica, pública e privada, para fins sociais'. Nele resulta consagrada, em sua integralidade - o segundo inciso da disposição autorizando a imposição de limites negativos e o terceiro a imposição de limites positivos à iniciativa econômica - a função social da iniciativa econômica, portanto a função social da empresa. $\mathrm{O}$ princípio está também consagrado no direito positivo brasileiro. $\mathrm{O}$ art. 154 e o parágrafo único do art. 116 da Lei 6.404/76 referem, de modo expresso, respectivamente, a função social da empresa e a função social da companhia. O princípio da função social da propriedade ganha substancialidade precisamente quando aplicado à propriedade dos bens de produção, ou seja, na disciplina jurídica da propriedade de tais bens, implementada sob compromisso com sua destinação. A propriedade sobre a qual os efeitos do princípio são refletidos com maior grau de intensidade é justamente a propriedade, em dinamismo, dos bens de produção. Na verdade, ao nos referirmos à função social dos bens de produção em dinamismo, estamos a aludir à função social da empresa.

Além disso, foram conferidas pela Constituição da República, pelo próprio Código Civil, pelo Estatuto da Cidade, pelo Estatuto da Terra, e por outras leis infraconstitucionais, às propriedades imobiliárias, urbana e rural, grande relevância, ainda que não se traduzam em bens de produção.

Estas espécies de propriedades imóveis ganham relevo na Constituição Federal, uma vez que dão suporte ao indivíduo e à coletividade conquistarem outros direitos sociais básicos, tal como o direito à moradia, ao trabalho, à alimentação, entre outros direitos e garantias fundamentais. Daí porque o cumprimento da função social é obrigatório, visto que se a propriedade não for funcionalizada (uma vez que os bens, naturalmente, são escassos), será causa de exclusão de tantos outros indivíduos ao seu acesso.

Em vista dessa crônica e histórica problemática de exclusão social, no capítulo da Constituição da República destinado à política agrícola e fundiária e da reforma agrária (artigos 184 a 191), verifica-se que o legislador originário se preocupou com a destinação da propriedade rural, vale dizer, criou suficientes mecanismos para expropriar a propriedade descumpridora do abordado mandamento constitucional.

Já o Código Civil, no $\$ 1^{\circ}$ do art. $1.228^{10}$, consagra mais uma vez o impositivo constitucional de que a propriedade atenderá a sua função social, disposição esta inexistente no antigo Código de Civil de 1916. Como se sabe, tal previsão neste Código poderia ser considerada desnecessária, haja vista que a Carta Magna já assim

10 Código Civil. Art. 1.228, $\$ 1^{\circ}$. O direito de propriedade deve ser exercido em consonância com as suas finalidades econômicas e sociais e de modo que sejam preservados, de conformidade com o estabelecido em lei especial, a flora, a fauna, as belezas naturais, $\mathrm{o}$ equilíbrio ecológico e o patrimônio histórico e artístico, bem como evitada a poluição do ar e das águas. vol.09, nº. 01, Rio de Janeiro, 2016.pp. 15-38 
dispunha e, pela conformidade de todo o ordenamento jurídico, todas as leis infraconstitucionais estariam condicionadas a serem legitimadas e interpretadas de acordo com aquela.

Não obstante, tem-se que os civilistas sempre foram arredios a qualquer "intromissão" da Constituição no direito privado, principalmente em razão da enorme estabilidade da legislação civil no decorrer dos séculos e das recorrentes mudanças constitucionais desde a independência do país. A respeito desses fatos, na atual Constituição, pontua Gustavo Tepedino (1999, p. 268):

A Constituição brasileira de 5 de outubro de 1988 introduziu profundas transformações na
disciplina da propriedade, no âmbito de uma ampla reforma de ordem econômica e social,
de tendência nitidamente intervencionista e solidarista.
Todavia, os civilistas não se deram conta de tais transformações em toda a sua amplitude,
mantendo-se condicionados à disciplina da propriedade pré-vigente. Uma confirmação
dessa constatação obtém-se do exame dos manuais, cujas edições, pós 1988, não trouxeram
alterações substanciais. Os autores limitaram-se a incluir nos antigos textos mudanças
pontuais ou supressões de simples preceitos não recebidos pela Constituição. Justifica-se,
por isso mesmo, o exame da evolução legislativa brasileira a partir do Código Civil, de
maneira a pôr em evidência a força transformadora do novo texto, estabelecendo os
contornos da propriedade privada no ordenamento jurídico atual.

Por sua vez, a Lei n 10.257 de 2001, o Estatuto da Cidade, veio a regulamentar os artigos 182 e 183 da Constituição Federal, estabelecendo diretrizes ao total desenvolvimento das funções sociais da cidade e à garantia do bem estar das pessoas, tarefa incumbida especialmente aos Municípios, mas não a eles somente.

Nesse ponto, José Isaac Pilati (2011, p. 76) ressalta o Plano Diretor previsto no Estatuto da Cidade, discutido e elaborado pela sociedade organizada para fazer frente aos prejuízos advindos de grupos especuladores, poluidores e outros, que não cumprem, assim sendo, a função social que lhes é incumbida, ao que considerar que:

No Plano Diretor é que se definem modelo de cidade e desenvolvimento, e consequentemente as balizas de função social da propriedade e da cidade. Será dentro de tais parâmetros que se harmonizam os conflitos, antecipando-se ao dano e à especulação irresponsável [...]. Assim, a Função Social abre espaço à autotutela da Sociedade.

O Estatuto da Cidade inovou o ordenamento jurídico ao prever nova modalidade de cumprimento da função social da propriedade, condicionando-a ao atendimento das exigências fundamentais de ordenação da cidade expressas no plano diretor (art. 182, $\$ 2^{\circ}$, da Constituição).

O referido diploma estabelece a desapropriação especial urbana, de natureza sancionatória, a ser executada pelo Município. É realizável em caso de renitência do proprietário em satisfazer as obrigações previstas na lei citadina, notadamente no caso de solo urbano não edificado, subutilizado ou não utilizado ( $a r t .182, \$ 4^{\circ}$ ), prevendo, sucessivamente, as seguintes medidas coercitivas: parcelamento ou edificação compulsórios; imposto sobre a propriedade predial e territorial urbana progressivo no tempo e desapropriação paga em títulos da dívida pública resgatáveis em até dez anos. 
A desapropriação especial urbana é, pois, instrumento de política urbana, com a específica finalidade, com base constitucional, de exigir do proprietário que utilize o bem imóvel urbano de forma promocional e positiva para com a sociedade, urbanizando-o.

Extrai-se dos ensinamentos de José Afonso da Silva (1995, p. 373) que a desapropriação urbanística:

Consubstancia um instrumento de execução da atividade urbanística do poder público, que tem, no planejamento, seu princípio nuclear. Ora, esse planejamento, ao estabelecer as bases da ordenação da realidade urbana, importa em conformar e configurar a propriedade imóvel e o direito de construir, atuando, no plano prático, o princípio constitucional da função social da propriedade.

Não se deve entender essa espécie de intervenção do Estado na propriedade, entretanto, como uma mera ferramenta para transferência de bens privados ao patrimônio público, mas como forma de alcançar uma utilização positiva da propriedade, direcionada ao bem comum, conforme estabeleça o plano diretor.

\section{O ENTENDIMENTO CONTEMPORÂNEO DA FUNÇÃO SOCIAL DA PROPRIEDADE}

A antiga concepção liberal da propriedade ainda é influente na jurisprudência brasileira. Os tribunais nacionais têm atrasado a penetração da função social na interpretação e na legitimação da propriedade. Essas primeiras conclusões tornam-se bastante plausíveis quando se discute a problemática da luta pela terra, na medida em que ela é um dos principais motores da efetividade social do princípio da função social da propriedade.

Analisar as ocupações de terra no Brasil de maneira individual seria de todo pretensioso, mas parte-se do pressuposto que são válidas e necessárias à busca por uma estrutura fundiária mais justa, sem excluir, todavia, a ocorrência de eventuais desvios cometidos pelos movimentos sociais no curso dessa jornada, sem, jamais, deslegitimar a luta desse estrato da sociedade. Em vista dessa questão, o Superior Tribunal de Justiça, contudo, recentemente editou a Súmula $354^{11}$, com a seguinte orientação aos tribunais inferiores: "A invasão do imóvel é causa de suspensão do processo expropriatório para fins de reforma agrária”. Esta súmula surgiu na tentativa de coibir novas ocupações de terras no país, como instrumento violento ao acesso à terra, ou quiçá, no próprio impedimento da melhor distribuição fundiária.

Explica o processualista civil Fredie Didier Jr. (DIDIER, 2015), ao discutir a tutela processual da posse, que:

O proprietário, para cumprir a função social da propriedade, precisa, obviamente, possuir a coisa; ou seja, a posse é o principal instrumento de exercício do direito de propriedade, que, comovisto, deveobservar os deveres fundamentais decorrentes daquela cláusula geral constitucional. A posse é, pois, o instrumento da concretização do dever constitucional de observância da função social da propriedade. 
Tem-se a partir da inteligência dessa passagem que se o proprietário não estiver de acordo com os ditames constitucionais da propriedade não lhe será concedida a tutela processual da posse. Por esta razão o mencionado processualista (DIDIER, 2015) defende que:

O art. 927 do CPC, que enumera os pressupostos para a concessão da proteção possessória, deve ser aplicado como se ali houvesse um novo inciso (o inciso V), que se reputa pressuposto implícito, decorrente do modelo constitucional de proteção da propriedade.

Continuando logicamente com o raciocínio, o possuidor que for turbado ou esbulhado em sua posse por "invasores" sem-terra, deverá comprovar estar a propriedade cumprindo com a função social, isto é, os seguintes requisitos, contidos no art. 186 da CR: aproveitamento racional e adequado; utilização adequada dos recursos naturais disponíveis e preservação do meio ambiente; observância das disposições que regulam as relações de trabalho; exploração que favoreça o bem-estar dos proprietários e dos trabalhadores.

O Superior Tribunal de Justiça confere igual tratamento à propriedade cumpridora da função social e aquela que não o obedece. Veja-se do REsp 897.265/RO, Rel. Ministro Mauro Campbell Marques, Segunda Turma, julgado em 24-8-2010:

PROCESSUAL CIVIL E ADMINISTRATIVO. RECURSO ESPECIAL DE INICIATIVA DO INCRA. REMESSA NECESSÁRIA. AUSÊNCIA DE APELAÇÃO POR PARTE DA FAZENDA PÚBLICA. PRELIMINAR DE OCORRÊNCIA DE PRECLUSÃO LÓGICA PARA A INTERPOSIÇÃO DE RECUSO ESPECIAL AFASTADA. ORIENTAÇÃO FIRMADA PELA CORTE ESPECIAL. ALEGADA VIOLAÇÃO AO ART. 535 DO CPC. AUSÊNCIA DE FUNDAMENTAÇÃO. SÚMULA 284/STF. AÇÃO DE DESAPROPRIAÇÃO PARA FINS DE REFORMA AGRÁRIA. INDENIZAÇÃO. JUROS COMPENSATÓRIOS. IRRELEVÂNCIA DE O IMÓVEL SER IMPRODUTIVO. [...]

A despeito de tal posicionamento, verifica-se que aquele Tribunal se oxigena continuamente com a já vintenária Constituição, de feição democrática e social, conforme se observa do AgRg no REsp 1138517/MG, Rel. Ministro Humberto Martins, Segunda Turma, julgado em 18-8-2011:

ADMINISTRATIVO. DESAPROPRIAÇÃO PARA FINS DE REFORMA AGRÁRIA. SUSPENSÃO DO PROCESSO EXPROPRIATÓRIO. MEDIDA CAUTELAR PELO JUIZ SINGULAR. POSSIBILIDADE. CONCEITO DE FUNÇÃO SOCIAL QUE NÃO SE RESUME À PRODUTIVIDADE DO IMÓVEL. DESCUMPRIMENTO DA FUNÇÃO SOCIAL NÃO RECONHECIDA PELA CORTE DE ORIGEM. MATÉRIA PROBATÓRIA. SÚMULA 7/STJ [...]

3. Nos moldes em que foi consagrado como um Direito Fundamental, o direito de propriedade tem uma finalidade específica, no sentido de que não representa um fim em si mesmo, mas sim um meio destinado a proteger o indivíduo e sua família contra as necessidades materiais.

Enquanto adstrita a essa finalidade, a propriedade consiste em um direito individual e, iniludivelmente, cumpre a sua função individual.

4. Em situação diferente, porém, encontra-se a propriedade de bens que, pela sua importância no campo da ordem econômica, não fica adstrita à finalidade de prover o sustento do indivíduo e o de sua família. Tal propriedade é representada basicamente pelos bens de produção, bem como, por aquilo que exceda o suficiente para o cumprimento da função individual. 
5. Sobre essa propriedade recai o influxo de outros interesses - que não os meramente individuais do proprietário - que a condicionam ao cumprimento de uma função social.

6. O cumprimento da função social exige do proprietário uma postura ativa. A função social torna a propriedade em um poder-dever. Para estar em conformidade com o Direito, em estado de licitude, o proprietário tem a obrigação de explorar a sua propriedade. É o que se observa, por exemplo, no art. 185, II, da CF.

7. Todavia, a função social da propriedade não se resume à exploração econômica do bem. A conduta ativa do proprietário deve operar-se de maneira racional, sustentável, em respeito aos ditames da justiça social, e como instrumento para a realização do fim de assegurar a todos uma existência digna.

8. Há, conforme se observa, uma nítida distinção entre a propriedade que realiza uma função individual e aquela condicionada pela função social. Enquanto a primeira exige que o proprietário não a utilize em prejuízo de outrem (sob pena de sofrer restrições decorrentes do poder de polícia), a segunda, de modo inverso, impõe a exploração do bem em benefício de terceiros.

9. Assim, nos termos dos arts. 186 da CF, e 9o da Lei n. 8.629/1993, a função social só estará sendo cumprida quando o proprietário promover a exploração racional e adequada de sua terra e, simultaneamente, respeitar a legislação trabalhista e ambiental, além de favorecer o bem-estar dos trabalhadores.

10. No caso concreto, a situação fática fixada pela instância ordinária é a de que não houve comprovação do descumprimento da função social da propriedade. Com efeito, não há como aferir se a propriedade - apesar de produtiva do ponto de vista econômico, este aliás, o único fato incontroverso - deixou de atender à função social por desrespeito aos requisitos constantes no art. $9^{\circ}$ da Lei n. 8.629/93.

$[\ldots]$.

Passando-se à crítica dos julgados do Supremo Tribunal Federal, observa-se a importância de seu posicionamento frente à função social da cidade no tocante ao IPTU progressivo. A progressividade do Imposto Territorial e Predial Urbano, além do mero cumprimento do princípio da capacidade contributiva (art.156, $\$ 1^{\circ}$, I, da Constituição da República), segundo o qual sua alíquota será distinta entre contribuintes com diferentes capacidades, é instrumento de extrafiscalidade para efetivação da função social da propriedade. Sobre o tema, colhe-se do escólio de Antonio Roque Carraza (2010, p. 120):

A Constituição quer que, além de obedecer ao princípio da capacidade contributiva, o IPTU tenha alíquotas diferentes de acordo com a localização e o uso do imóvel, de forma a assegurar o cumprimento da função social da propriedade (nos termos do plano diretor). Em outras palavras, além de obedecer a uma progressividade fiscal (exigida pelo $₫ 1^{\circ}$ do art. 145 , c.c o inciso I do art. 156, ambos da CF), o IPTU deverá submeter-se a uma progressividade extrafiscal (determinada no inciso II do $\$ 1^{\circ}$ do art. $156 \mathrm{da} \mathrm{CF}$ ). Somente a progressividade extrafiscal depende da edição do plano diretor, que indicará qual a melhor localização e o uso mais adequado do imóvel urbano.

Portanto, o IPTU pode e deve ser um instrumento de extrafiscalidade.

O STF, na esteira deste pensamento, consolidou posicionamento no RE 590360 AgR, Rel. Min. Celso de Mello, Segunda Turma, julgado em 31-5-2011:

IPTU - PROGRESSIVIDADE DA ALÍQUOTA - FUNÇÃO SOCIAL DA PROPRIEDADE - FINALIDADE EXTRAFISCAL - NECESSIDADE DE LEI NACIONAL - RECURSO DE AGRAVO IMPROVIDO. - A Constituição Federal de 1988, ao delinear o esquema normativo pertinente ao IPTU, contemplou a possibilidade de essa espécie tributária ser progressiva, em ordem a assegurar o cumprimento da função social

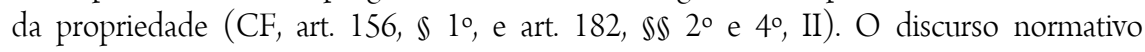


consubstanciado nesses preceitos constitucionais evidencia que a progressividade do IPTU, no sistema instaurado pela Constituição da República, assume uma nítida qualificação extrafiscal. - A jurisprudência do Supremo Tribunal Federal firmou-se no sentido de que a única progressividade admitida pela Carta Política, em tema de IPTU, é aquela de caráter extrafiscal, vocacionada a garantir o cumprimento da função social da propriedade urbana, desde que estritamente observados os requisitos fixados pelo art. 156, $\$ 1^{\circ}$, e, também, pelo art. 182, \$ 4º, II, ambos da Constituição da República. Precedente (Pleno)

No entender de José Isaac Pilati (2011, p. 114), “a progressividade seria um reforçador da função social da propriedade, integrando-a com a política e as exigências da ordenação citadina”.

Deve ser pontuado, por outro lado, que a previsão da função social no Código Civil, apesar de reforçar o instituto, também pode restringir a sua contínua reanálise pelo Supremo Tribunal Federal, nos casos em que for este o objeto de apreciação. Isso porque, ao ser previsto em lei infraconstitucional, são totalmente inviabilizados recursos àquele Tribunal, visto que a ofensa à Constituição seria meramente reflexa ou indireta.

\section{O ALCANCE DA FUNÇÃO SOCIAL E O PERDIMENTO DA PROPRIEDADE}

A propriedade hodierna, especialmente dos bens de produção e daquelas imobiliárias localizadas em área rural, justifica-se pela sua função, isto é, a função social é a sua própria razão de ser, conforme apurado anteriormente.

Fixadas essas premissas, segundo a qual a função social é componente estruturante e justificador da propriedade, insofismavelmente haverá fato jurídico extintivo do direito de propriedade, visto que a ela faltará elemento nuclear para constituir e fazer permanecer este fato jurídico de natureza real, bem como produzir efeitos.

Logo, a propriedade-função, a única protegida na Constituição do Brasil, continuará existindo, por ser dotada de função social. Entretanto, convivem propriedades funcionalizadas e propriedades não funcionalizadas, devendo ser tratadas de desigualmente.

Esse desigual tratamento de propriedades pode ser aplicado no tocante à desapropriação, conforme expõe Eros Roberto Grau (2007, p. 299):

Ainda no que tange à propriedade, o tratamento conferido àquela dotada de função social é contraditório.

Deveras, esta - a propriedade dotada de função social- justifica-se, como vimos, pelos seus fins, sua função; é justamente sua função que a legitima.

Assim, se a partir deste ponto deixarmos fluir coerentemente o raciocínio, forçosamente concluiremos que 'a propriedade dotada de função social, que não esteja a cumpri-la, já não será mais objeto de proteção jurídica’. Ou seja, já não haverá mais fundamento jurídico a atribuir direito de propriedade ao titular do bem (propriedade) que não está a cumprir a função social. Em outros termos: já não há mais, no caso, bem que possa, juridicamente, ser objeto de direito de propriedade.

Logo - sigo pelo caminho de raciocínio, coerentemente - não há, na hipótese de propriedade que não cumpre sua função social, 'propriedade' desapropriável. Pois é evidente que só se pode desapropriar a propriedade; onde ela não existe, não há o que desapropriar. 
Em consequência - prossigo, em caso como tal, o Estado 'desapropria' essa 'propriedade' (que não cumpre sua função social, repita-se), indenizando o 'proprietário', o pagamento dessa indenização consubstancia pagamento indevido, ao qual corresponderá o enriquecimento sem causa do 'proprietário'.

A hipótese, se no mínimo de coerência nos for exigido, há de conduzir ao perdimento do beme não a essa estranha 'desapropriação'.

Ao não possuir intrinsecamente a justificação de sua existência e eficácia em razão da função social, entende-se pelo perecimento da coisa (art. 1.275, inciso IV, do Código Civil). A propriedade, desse modo, pereceu por não possuir, dentre as suas características essenciais, o principal componente de seu próprio objeto.

Essa questão já foi objeto de julgamento no Superior Tribunal de Justiça (BRASIL, 2005), que reconheceu o perecimento da propriedade loteada que sofreu paulatina ocupação de moradores sem teto:

CIVIL E PROCESSUAL. AÇÃO REIVINDICATÓRIA. TERRENOS DE LOTEAMENTO SITUADOS EM ÁREA FAVELIZADA. PERECIMENTO DO DIREITO DE PROPRIEDADE. ABANDONO. CC, ARTS. 524, 589, 77 E 78. MATÉRIA DE FATO. REEXAME. IMPOSSIBILIDADE. SÚMULA N. 7-STJ.

I. O direito de propriedade assegurado no art. 524 do Código Civil anterior não é absoluto, ocorrendo a sua perda em face do abandono de terrenos de loteamento que não chegou a ser concretamente implantado, e que foi paulatinamente favelizado ao longo do tempo, com a desfiguração das frações e arruamento originariamente previstos, consolidada, no local, uma nova realidade social e urbanística, consubstanciando a hipótese prevista nos arts. 589 c/c 77 e 78 , da mesma lei substantiva.

II. "A pretensão de simples reexame de prova não enseja recurso especial" - Súmula n. 7-STJ.

III. Recurso especial não conhecido.

O julgado acima, que reconheceu o perecimento da propriedade em razão do uso efetuado por moradores que a ocuparam, apesar de não se referir explicitamente à função social da propriedade, por certo a possui como pressuposto e é sustentado por um entendimento de que a propriedade pertence àquele que the dá finalidade social

Não obstante, além dos casos de perecimento do objeto, possível também verificar a ocorrência de abandono (art. 1.275, inciso II, do Código Civil), segundo o qual o proprietário, voluntariamente, se desfaz da propriedade. Frise-se que ao imóvel abandonado o Código Civil incluiu o art. 1276, o qual revela o procedimento de perda da propriedade dos bens vagos, tanto dos imóveis urbanos (art. 1.276, "caput", do Código Civil), quanto dos imóveis rurais (art. 1.276, $\mathbb{S} 1^{\circ}$, do Código Civil) aos Municípios e Distrito Federal, conforme assim determina.

Este dispositivo incluído no novo Código, "consagra uma das mais relevantes inovações do Código Civil, derrubando um dos dogmas do direito privado: a propriedade não se perder pelo não uso" (LOUREIRO, 2010, p. 1.278). Não obstante, veio a coroar a necessidade de se cumprir a função social, seja da posse ou da propriedade, a qual obriga o proprietário, segundo seus poderes inscritos no art. 1.228 do Código Civil, a ter uma conduta positiva na administração de sua propriedade. 
Configurados os requisitos do art. 1.276 do Código Civil, serão os imóveis (assim como os bens de produção eventualmente nele inseridos, por consequência), arrecadados pela Municipalidade, observando, contudo, o devido processo legal, de forma que o proprietário possa se defender e provar o não abandono de seu imóvel 2 .

Por esta razão, Luiz Edson Fachin, ao atualizar a obra de Orlando Gomes (2010, p. 108), leciona:

A situação jurídica 'propriedade' exige o cumprimento de sua função social para que seja dotada de existência e eficácia. Deste modo, propriedade que não cumpre função social não pode ser tutelada como tal no ordenamento jurídico brasileiro.

Por existência e eficácia, entende Marcos Bernardes de Mello (1986, p. 94-96):

No plano da existência não se cogita de invalidade ou eficácia do fato jurídico, importa, apenas, a realidade da existência. Tudo, aqui, fica circunscrito a se saber se o suporte fáctico suficiente se compôs, dando ensejo à incidência. Naturalmente, se há falta, no suporte fáctico, de elemento nuclear, mesmo complementar do núcleo, o fato não tem entrada no plano da existência, donde não haver fato jurídico.

[...]

O plano da eficácia é a parte do mundo jurídico onde fatos jurídicos produzem os seus efeitos, criando as situações jurídicas, as relações jurídicas, com todo o seu conteúdo eficacial representado pelos direitos e deveres, pretensões e obrigações, ações e exceções, ou os extinguindo.

Vislumbrando-se a ausência da situação jurídica "propriedade" para aqueles bens não funcionalizados, não se lhes poderá atribuir existência e eficácia. Sendo assim, por não existir, e por via de consequência, não surtir efeitos, deverá esta "propriedade" descumpridora da função social ser devidamente excluída do mundo não jurídico, uma vez que não admitida pelo ordenamento jurídico brasileiro.

\section{CONSIDERAÇÕES FINAIS}

O tema da propriedade e sua função social foi escolhido com o intuito de tensionar ao máximo o alcance da aplicação do dispositivo constitucional que obriga o atendimento da função social da propriedade privada, elemento este que é central no sistema econômico atual, de forma que uma diferente interpretação do instituto possa trazer benefícios e soluções à problemática social presente no País.

Conforme se pôde observar através da pesquisa nas obras de parte dos mais tradicionais juristas deste país, o tema sofre por eles preconceito, motivo pelo qual sua abordagem tende a ser de forma limitada e superficial, não the conferindo tratamento adequado e não demonstrando seu longo alcance. Por esta razão, foram privilegiados autores que já realizaram o giro democrático da Constituição da República de 1988, tais como Fábio Konder Comparato e José Afonso da Silva, bem como do civilista Orlando Gomes, que, por certo, foi um homem à frente de seu tempo.

Os contornos e os limites da propriedade e sua função social foram traçados: diferenciaram-se as limitações jurídicas da função social e foram apontadas quais espécies de propriedade são obrigadas a cumprir o 
mandamento constitucional e aquelas que possuem apenas função individual ou de fruição imediata. Assim, concluiu-se que a propriedade atual, mais que "possuir" finalidade social, ela "é" finalidade social, haja vista, na expressão de Orlando Gomes, ser a função social a sua própria ratio.

Firma-se, portanto, o entendimento de que a propriedade somente deverá ser considerada e protegida como tal se efetivadora da função social, isto é, se os poderes inerentes ao proprietário estiverem direcionados a um determinado fim, previsto constitucionalmente.

Ao entender a função social como componente estruturante e justificador da propriedade, considerado como a sua própria razão de ser, insofismavelmente aquela que não atenda a função social deverá ser repudiada pelo ordenamento jurídico, nos âmbitos material e processual. Vale dizer, para irradiar seus efeitos nessas esferas, a propriedade deverá estar em consonância com as normas constitucionais e infraconstitucionais que a rege.

Sendo assim, a propriedade-função, a única protegida na Constituição do Brasil, continuará existindo e possuindo eficácia, por ser dotada de função social. A propriedade que não desempenhe sua finalidade social, como se verifica, não é somente repelida nos âmbitos social e econômico, mas também na esfera jurídica.

\title{
THE PROPERTY AXIOLOGICAL-REGULATORY CONTENT AND ITS SOCIAL FUNCTION
}

\begin{abstract}
This article aims to analyze the conformation of the 1988 post-Constitution property rights Therefore, it is a brief summary of its political and economic content and the interaction it plays in capitalist economic mode of production from the value of theory Adam Smith, pointing out the consequences in the nascent Brazilian capitalism. Nevertheless, investigates the republican constitutions of Brazil and the design that give it, so as to analyze the current property-function and its promotional character, which, of course, has no socialist inspiration. Is, moreover, in line with a solidarist economy and committed to social justice and material equality. In this sense, it differs from the social function of the legal limitation of the property, as to that is a positive character and inserts in their own content and the limitation is of negative nature and finds himself on the outside of the institute. After, which differs from the property that is necessarily linked to the fulfillment of the social function, especially of productive assets and property, that property that has only individual or immediate enjoyment function. Are addressed also be judged from the higher courts of Brazil, noting sometimes conservative positions, sometimes understandings oxygenates the new conformation of property rights in line with its inherent social function. By order, we discuss aspects of existence and effectiveness of property that does not have social purpose.
\end{abstract}

Keywords: Constitutional law. Civil Law. Property. Social function. 


\section{REFERENCIAS}

BANDEIRA DE MELLO, Celso Antônio. Curso de direito administrativo. 27a ed. São Paulo: Malheiros, 2010;

BARBOSA, Ruy. Comentários à Constituição Federal Brasileira, Tomo II, São Paulo, 1933;

BERCOVICI, Gilberto. A problemática da constituição dirigente: algumas considerações sobre o caso brasileiro. Revista de Informação Legislativa, n. 142. Ano 36, 1999;

BONAVIDES, Paulo. Curso de direito constitucional. 22a ed. São Paulo: Malheiros, 2010;

BRASIL. Lei n. 10.406, de 10 de janeiro de 2002. Institui do Código Civil; 08/09/2008;

Superior Tribunal de Justiça. Súmula 354, PRIMEIRA SEÇÃO, julgado em 25/06/2008, DJe Superior Tribunal de Justiça. REsp 75659/SP, Rel. Ministro ALDIR PASSARINHO JUNIOR, QUARTA TURMA, julgado em 21/06/2005, DJ 29/08/2005, p. 344.

CARRAZZA, Antonio Roque. Curso de Direito Constitucional Tributário. São Paulo: Malheiros, 2010;

COELHO, Fábio Ulhoa. Curso de direito comercial, volume 1. 1 1ª. ed., São Paulo: Saraiva, 2007;

COMPARATO, Fábio Konder. Função social da propriedade dos bens de produção. RDM 63/73;

DIDIER JR, Fredie. Função social da propriedade e a tutela processual da posse. Disponível em: http://direitosreais.files.wordpress.com/2009/03/a-funcao-social-e-a-tutela-da-posse-fredie-didier.pdf Acesso em 25.05.2015;

DINIZ, Maria Helena. Código Civil Anotado. 12a ed. São Paulo: Saraiva, 2006;

FRANÇA. Declaração dos direitos do homem e do cidadão. 2 de outubro de 1789. Assembleia Nacional Constituinte. Disponível em: http://pfdc.pgr.mpf.gov.br/atuacao-e-conteudos-de-apoio/legislacao/direitoshumanos/declar_dir_homem_cidadao.pdf. Acesso em 03 de julho de 2015;

Leis, decretos, etc. Código Napoleão: ou código civil dos franceses. Rio de Janeiro: Record, 1962;

GADELHA, Regina M. D'Aquino Fonseca. A lei de terra (1850) e a abolição da escravidão, capitalismo e força de trabalho no Brasil do século XIX. Revista de História, n. ${ }^{\circ}$ 120, p. 153-162, 1989.

GILISSEN, John. Introdução histórica ao direito. Trad. A. M. Hespanha e L. M. Macaísta Malheiros. 7a ed. Lisboa: Fundação Lacouste Gulbenkian, 2013.

GOMES, Orlando. Direitos Reais. 20a ed. Rio de Janeiro: Forense, 2010;

A função Social da Propriedade. In: Boletim da Faculdade de Direito de Coimbra, n. especial (Estudos em Homenagem ao Prof. Dr. Ferrer-Correia), 1989;

GONÇAVES, Carlos Roberto. Direito civil brasileiro. Volume 5: direito das coisas. $5^{a}$ ed. São Paulo: Saraiva, 2010; 
GRAU, Eros Roberto. A ordem econômica na constituição de 1988 (interpretação e crítica). 12a ed. São Paulo: Malheiros, 2007;

LEÃO XIII. Rerum novarum. Carta encíclica sobre a condição dos operários. São Paulo: Loyola, 1991.

LOCKE, John. Segundo tratado do governo civil. Trad. Magda Lopes e Marisa Lobo da Costa. São Paulo: Editora Vozes, 2009;

LOUREIRO, Francisco Eduardo. Código Civil comentado: doutrina e jurisprudência. Coordenador: Cézar Peluso. 4a ed. Barueri: Editora Manole, 2010;

MEIRELES, Hely Lopes. Direito administrativo brasileiro. 36ª ed. São Paulo: Malheiros, 01.2010;

MELLO, Marcos Bernandes de. Teoria do fato jurídico. 2a ed. São Paulo: Saraiva, 1986;

MIRANDA, Pontes de. Tratado de direito privado. $1^{\text {a }}$ ed. Tomo XI. Campinas: Bookseller, 2001;

PACHUKANIS, Evgeni Bronislávovich. Teoria geral do direito e marxismo. Trad: Sílvio Donizete Chagas. São Paulo: Editoria Acadêmica, 1988;

PERLINGIERI, Pietro. Perfis de direito civil: introdução ao direito civil constitucional. Trad. Maria Cristina de Cicco. Rio de Janeiro: Renovar, 2007;

PILATI, José Isaac. Propriedade \& função na pós-modernidade. Rio de Janeiro: Lumen Juris, 2011;

RENNER, Karl. Institucions of private Law and their social functions. Trad. Agnes Schwarzschild. London: Routledge \& Kegan Paul, 1949;

SILVA, José Afonso da. Aplicabilidade das normas constitucionais. 3a ed. São Paulo: Malheiros, 1998; Curso de direito constitucional positivo. 22. ${ }^{a}$ ed. São Paulo: Malheiros, 2003; Direito urbanístico brasileiro. São Paulo: Malheiros, 1995;

SMITH, Adam. A riqueza das nações: investigação sobre sua natureza e suas causas. vol. 2. Trad. Luiz João Baraúna. São Paulo: Nova Cultural, 1996;

TEPEDINO, Gustavo. Temas de direito civil. Rio de Janeiro: Renovar, 1999.

Trabalho enviado em 01 de junho de 2015.

Aceito em 08 de agosto de 2015. 